\title{
Succinate receptor in GtoPdb v.2021.3
}

\author{
Anthony P. Davenport ${ }^{1}$, Julien Hanson ${ }^{2}$ and Wen Chiy Liew ${ }^{3}$
}

1. University of Cambridge, UK

2. University of Liege, Belgium

3. University of Edinburgh, UK

\begin{abstract}
Nomenclature as recommended by NC-IUPHAR [8]. The Succinate receptor was identified as being activated by physiological levels of the Kreb's cycle intermediate succinate and other dicarboxylic acids such as maleate in 2004. Since its pairing with its endogenous ligand, the receptor has been the focus of intensive research and its role has been evidenced in various (patho)physiological processes such as regulation of renin production, retinal angiogenesis, inflammation or the immune response.
\end{abstract}

\section{Contents}

This is a citation summary for Succinate receptor in the Guide to Pharmacology database (GtoPdb). It exists purely as an adjunct to the database to facilitate the recognition of citations to and from the database by citation analyzers. Readers will almost certainly want to visit the relevant sections of the database which are given here under database links.

GtoPdb is an expert-driven guide to pharmacological targets and the substances that act on them. GtoPdb is a reference work which is most usefully represented as an on-line database. As in any publication this work should be appropriately cited, and the papers it cites should also be recognized. This document provides a citation for the relevant parts of the database, and also provides a reference list for the research cited by those parts. For further details see [5].

Please note that the database version for the citations given in GtoPdb are to the most recent preceding version in which the family or its subfamilies and targets were substantially changed. The links below are to the current version. If you need to consult the cited version, rather than the most recent version, please contact the GtoPdb curators.

\section{Database links}

Succinate receptor

https://www.guidetopharmacology.org/GRAC/FamilyDisplayForward?familyId=446

Introduction to Succinate receptor

https://www.guidetopharmacology.org/GRAC/FamilyIntroductionForward?familyId=446

Receptors

succinate receptor

https://www.guidetopharmacology.org/GRAC/ObjectDisplayForward?objectId=166

\section{References}

1. Abbracchio MP, Burnstock G, Boeynaems JM, Barnard EA, Boyer JL, Kennedy C, Knight GE, Fumagalli M, Gachet C and Jacobson KA et al.. (2006) International Union of Pharmacology LVIII: update on the P2Y G protein-coupled nucleotide receptors: from molecular mechanisms and pathophysiology to therapy. Pharmacol Rev 58: 281-341 [PMID:16968944]

2. Aguiar CJ, Andrade VL, Gomes ER, Alves MN, Ladeira MS, Pinheiro AC, Gomes DA, Almeida AP, Goes AM and Resende RR et al.. (2010) Succinate modulates $\mathrm{Ca}(2+)$ transient and cardiomyocyte viability through PKA-dependent pathway. Cell Calcium 47: 37-46 [PMID:20018372]

3. Ariza AC, Deen PM and Robben JH. (2012) The succinate receptor as a novel therapeutic target 
for oxidative and metabolic stress-related conditions. Front Endocrinol (Lausanne) 3: 22 [PMID:22649411]

4. Bhuniya D, Umrani D, Dave B, Salunke D, Kukreja G, Gundu J, Naykodi M, Shaikh NS, Shitole P and Kurhade S et al.. (2011) Discovery of a potent and selective small molecule hGPR91 antagonist. Bioorg Med Chem Lett 21: 3596-602 [PMID:21571530]

5. Buneman P, Christie G, Davies JA, Dimitrellou R, Harding SD, Pawson AJ, Sharman JL and Wu Y. (2020) Why data citation isn't working, and what to do about it Database 2020 [PMID:32367113]

6. Cantagrel V, Lossi AM, Boulanger S, Depetris D, Mattei MG, Gecz J, Schwartz CE, Van Maldergem L and Villard L. (2004) Disruption of a new X linked gene highly expressed in brain in a family with two mentally retarded males. J Med Genet 41: 736-42 [PMID:15466006]

7. Correa PR, Kruglov EA, Thompson M, Leite MF, Dranoff JA and Nathanson MH. (2007) Succinate is a paracrine signal for liver damage. J Hepatol 47: 262-9 [PMID:17451837]

8. Davenport AP, Alexander SP, Sharman JL, Pawson AJ, Benson HE, Monaghan AE, Liew WC, Mpamhanga CP, Bonner TI and Neubig RR et al.. (2013) International Union of Basic and Clinical Pharmacology. LXXXVIII. G protein-coupled receptor list: recommendations for new pairings with cognate ligands. Pharmacol Rev 65: 967-86 [PMID:23686350]

9. Fredriksson R, Lagerström MC, Lundin LG and Schiöth HB. (2003) The G-protein-coupled receptors in the human genome form five main families. Phylogenetic analysis, paralogon groups, and fingerprints. Mol Pharmacol 63: 1256-72 [PMID:12761335]

10. Geubelle P, Gilissen J, Dilly S, Poma L, Dupuis N, Laschet C, Abboud D, Inoue A, Jouret F and Pirotte B et al.. (2017) Identification and pharmacological characterization of succinate receptor agonists. Br J Pharmacol 174: 796-808 [PMID:28160606]

11. Gilissen J, Geubelle P, Dupuis N, Laschet C, Pirotte B and Hanson J. (2015) Forskolin-free cAMP assay for Gi-coupled receptors. Biochem Pharmacol 98: 381-91 [PMID:26386312]

12. Gnana-Prakasam JP, Ananth S, Prasad PD, Zhang M, Atherton SS, Martin PM, Smith SB and Ganapathy V. (2011) Expression and iron-dependent regulation of succinate receptor GPR91 in retinal pigment epithelium. Invest Ophthalmol Vis Sci 52: 3751-8 [PMID:21357408]

13. Gonzalez NS, Communi D, Hannedouche S and Boeynaems JM. (2004) The fate of P2Y-related orphan receptors: GPR80/99 and GPR91 are receptors of dicarboxylic acids. Purinergic Signal 1: 17-20 [PMID:18404396]

14. Haffke M, Fehlmann D, Rummel G, Boivineau J, Duckely M, Gommermann N, Cotesta S, Sirockin F, Freuler F and Littlewood-Evans A et al.. (2019) Structural basis of species-selective antagonist binding to the succinate receptor. Nature 574: 581-585 [PMID:31645725]

15. Hakak Y, Lehmann-Bruinsma K, Phillips S, Le T, Liaw C, Connolly DT and Behan DP. (2009) The role of the GPR91 ligand succinate in hematopoiesis. J Leukoc Biol 85: 837-43 [PMID:19204147]

16. He W, Miao FJ, Lin DC, Schwandner RT, Wang Z, Gao J, Chen JL, Tian H and Ling L. (2004) Citric acid cycle intermediates as ligands for orphan G-protein-coupled receptors. Nature 429: 188-93 [PMID:15141213]

17. Hebert SC. (2004) Physiology: orphan detectors of metabolism. Nature 429: 143-5 [PMID:15141197]

18. Högberg C, Gidlöf O, Tan C, Svensson S, Nilsson-Öhman J, Erlinge D and Olde B. (2011) Succinate independently stimulates full platelet activation via cAMP and phosphoinositide 3kinase- $\beta$ signaling. $J$ Thromb Haemost 9: 361-72 [PMID:21143371]

19. Joost $\mathrm{P}$ and Methner A. (2002) Phylogenetic analysis of 277 human G-protein-coupled receptors as a tool for the prediction of orphan receptor ligands. Genome Biol 3: RESEARCH0063 [PMID:12429062]

20. Littlewood-Evans A, Sarret S, Apfel V, Loesle P, Dawson J, Zhang J, Muller A, Tigani B, Kneuer R and Patel S et al.. (2016) GPR91 senses extracellular succinate released from inflammatory macrophages and exacerbates rheumatoid arthritis. J Exp Med 213: 1655-62 [PMID:27481132]

21. Macaulay IC, Tijssen MR, Thijssen-Timmer DC, Gusnanto A, Steward M, Burns P, Langford CF, Ellis PD, Dudbridge F, Zwaginga JJ, Watkins NA, van der Schoot CE and Ouwehand WH. (2007) Comparative gene expression profiling of in vitro differentiated megakaryocytes and erythroblasts identifies novel activatory and inhibitory platelet membrane proteins. Blood 109: 3260-9 [PMID:17192395]

22. Molnár T, Héja L, Emri Z, Simon A, Nyitrai G, Pál I and Kardos J. (2011) Activation of astroglial calcium signaling by endogenous metabolites succinate and gamma-hydroxybutyrate in the nucleus accumbens. Front Neuroenergetics 3: 7 [PMID:22180742]

23. Regard JB, Sato IT and Coughlin SR. (2008) Anatomical profiling of G protein-coupled receptor expression. Cell 135: 561-71 [PMID:18984166]

24. Rexen Ulven E, Trauelsen M, Brvar M, Lückmann M, Bielefeldt L $\varnothing$, Jensen LKI, Schwartz TW and Frimurer TM. (2018) Structure-Activity Investigations and Optimisations of Non-metabolite Agonists for the Succinate Receptor 1. Sci Rep 8: 10010 [PMID:29968758]

25. Rubic T, Lametschwandtner G, Jost S, Hinteregger S, Kund J, Carballido-Perrig N, Schwärzler C Junt T, Voshol H and Meingassner JG et al.. (2008) Triggering the succinate receptor GPR91 on 
dendritic cells enhances immunity. Nat Immunol 9: 1261-9 [PMID:18820681]

26. Rubić-Schneider T, Carballido-Perrig N, Regairaz C, Raad L, Jost S, Rauld C, Christen B, Wieczorek G, Kreutzer R and Dawson J et al.. (2017) GPR91 deficiency exacerbates allergic contact dermatitis while reducing arthritic disease in mice. Allergy 72: 444-452 [PMID:27527650]

27. Sapieha P, Sirinyan M, Hamel D, Zaniolo K, Joyal JS, Cho JH, Honoré JC, Kermorvant-Duchemin E, Varma DR and Tremblay S et al.. (2008) The succinate receptor GPR91 in neurons has a major role in retinal angiogenesis. Nat Med 14: 1067-76 [PMID:18836459]

28. Southern C, Cook JM, Neetoo-Isseljee Z, Taylor DL, Kettleborough CA, Merritt A, Bassoni DL, Raab WJ, Quinn E and Wehrman TS et al.. (2013) Screening B-Arrestin Recruitment for the Identification of Natural Ligands for Orphan G-Protein-Coupled Receptors. J Biomol Screen 18: 599-609 [PMID:23396314]

29. Sundström L, Greasley PJ, Engberg S, Wallander M and Ryberg E. (2013) Succinate receptor

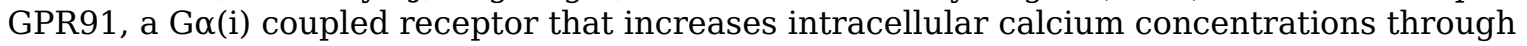
PLCß. FEBS Lett 587: 2399-404 [PMID:23770096]

30. Toma I, Kang JJ, Sipos A, Vargas S, Bansal E, Hanner F, Meer E and Peti-Peterdi J. (2008) Succinate receptor GPR91 provides a direct link between high glucose levels and renin release in murine and rabbit kidney. J Clin Invest 118: 2526-34 [PMID:18535668]

31. Trauelsen M, Rexen Ulven E, Hjorth SA, Brvar M, Monaco C, Frimurer TM and Schwartz TW. (2017) Receptor structure-based discovery of non-metabolite agonists for the succinate receptor GPR91. Mol Metab 6: 1585-1596 [PMID:29157600]

32. Vargas SL, Toma I, Kang JJ, Meer EJ and Peti-Peterdi J. (2009) Activation of the succinate receptor GPR91 in macula densa cells causes renin release. J Am Soc Nephrol 20: 1002-11 [PMID:19389848]

33. Wittenberger T, Schaller HC and Hellebrand S. (2001) An expressed sequence tag (EST) data mining strategy succeeding in the discovery of new G-protein coupled receptors. J Mol Biol 307: 799-813 [PMID:11273702]

34. Zhang D, Gao ZG, Zhang K, Kiselev E, Crane S, Wang J, Paoletta S, Yi C, Ma L and Zhang W et al.. (2015) Two disparate ligand-binding sites in the human P2Y1 receptor. Nature 520: 317-21 [PMID:25822790]

35. Zhang J, Zhang K, Gao ZG, Paoletta S, Zhang D, Han GW, Li T, Ma L, Zhang W and Müller CE et al.. (2014) Agonist-bound structure of the human P2Y12 receptor. Nature 509: 119-22 [PMID:24784220]

36. Zhang K, Zhang J, Gao ZG, Zhang D, Zhu L, Han GW, Moss SM, Paoletta S, Kiselev E and Lu W et al.. (2014) Structure of the human P2Y12 receptor in complex with an antithrombotic drug. Nature 509: 115-8 [PMID:24670650] 